\title{
SCREENING OF HUNGARIAN CATTLE HERDS FOR MYCOPLASMA MYCOIDES SUBSPECIES MYCOIDES SMALL COLONY INFECTION WITH NEGATIVE RESULTS
}

\author{
L. StIPKOVITS ${ }^{1 *}$, Á. DÁN $^{1}$, Erika VARGA ${ }^{1}$, Paula De SANTIS ${ }^{2}$, Rosella Lelly ${ }^{2}$, \\ Éva KASZANYITZKY ${ }^{3}$, Ildikó FerencZné PALUSKA ${ }^{1}$, M. TENK ${ }^{1}$, L. TeKES ${ }^{3}$ \\ and B. HARRACH ${ }^{1}$ \\ ${ }^{1}$ Veterinary Medical Research Institute, Hungarian Academy of Sciences, P.O. Box 18, \\ H-1581 Budapest, Hungary; ${ }^{2}$ Zooprofilattico Sperimentale dell Abruzzo e del Molise \\ 'G. Caporale', Teramo, Italy; ${ }^{3}$ Central Veterinary Institute, Budapest, Hungary
}

(Received April 10, 2000; accepted May 3, 2000)

\begin{abstract}
At abattoirs and farms, 1248 sera were collected from animals representing 121 farms, and examined by complement fixation test using Mycoplasma mycoides subspecies mycoides small colony type (MmmSC) antigen. All sera were negative except seven from four farms, giving ++ reactions in the serum dilution of 1:10. On retesting, these sera and additional 30 sera collected repeatedly in both farms gave negative results. In isolation attempts, 953 lung samples collected from slaughtered cattle at the same abattoirs, and 326 nasal swabs collected from 11 herds proved to be negative for the presence of MmmSC, but M. bovis was isolated frequently. In the small farms $23.95 \%$ of the animals had pleurisy and/or pneumonia while in the large herds $34.69 \%$ had lesions. DNA extracted from 50 nasal swabs and 430 lung samples was examined by polymerase chain reaction (PCR) using M. mycoides cluster-specific primers. DNA from further 325 lung samples was tested by the more specific M. mycoides subspecies mycoides small colony/large colony/capri specific primers and 196 samples by nested PCR specific for MmmSC. All gave negative results. The detection level of cluster-specific primers and the more specific primers was $33.4 \mathrm{pg}$ of DNA, whereas that of nested PCR was $0.33 \mathrm{pg}$.
\end{abstract}

Key words: Contagious bovine pleuropneumonia, culturing of Mycoplasma mycoides subsp. mycoides SC, M. bovis, complement fixation test, PCR

Contagious bovine pleuropneumonia (CBPP) is a disease belonging to the 'List A diseases' of the 'Office International des Epizooties' (Ter Laak, 1992a) and listed among the six priority diseases under the FAO Emergency Prevention System (EMPRES) (Rweyemamu and Benkirane, 1996) because of its potential for transmissibility and the serious socioeconomic consequences. The disease causes considerable economic losses in Africa and Asia for which special measures leading to its eradication must be taken (Miserez et al., 1997). CBPP is caused by Mycoplasma mycoides subspecies mycoides small colony type

\footnotetext{
*E-mail: stipkovits@novell.vmri.hu; Fax: +36 (1) 467-4083; +36 (1) 252-1076
} 
(MmmSC). Diagnosis of the disease is difficult. Although clinical symptoms and pathological lesions are considered pathognomonic in endemic areas, they also might be non-characteristic, with a long incubation period. Furthermore, the partial resistance of animals enhances the spread of infection relatively unnoticed. The complement fixation test (CFT), which is regarded as an official serological method for antibody detection, can demonstrate only approximately $74 \%$ of the infected animals (Nicholas and Bashiruddin, 1995). The increasing use of antibiotics in Europe may mask clinical signs and lesions as well as serological response (Nicholas and Palmer, 1994). The very sensitive PCR test is not always used and impurity may cause false positive reactions (Akane et al., 1994; Cheng et al., 1995; Miserez et al., 1997). Finally, the presence of different (but biochemically and serologically very closely related) members of the M. mycoides cluster (Taylor et al., 1992; Dedieu et al., 1994; Frey et al., 1995; Hotzel and Sachse, 1996; Johansson et al., 1996; Petterson et al., 1996) may also cause problems. The relaxation of import controls on animal movements throughout the European Union and the general increase in international trade have increased the threat of CBPP to disease-free countries.

Europe was considered to be free of CBPP from the end of the last century. However, some years ago, outbreaks of CBPP were recognised in cattle in Portugal, Spain, France and Italy (Santini et al., 1992; Bashiruddin et al., 1994a, $b$; Nicholas and Bashiruddin, 1995; De Santis et al., 1996a, b; Egwu et al., 1996; Ayling et al., 1998). It was supposed that the MmmSC infection was transmitted from Africa. However, comparative Southern blot hybridisation with an insertion sequence, IS1296 (Frey et al., 1995) of strains obtained from different outbreaks of European and African countries revealed that European isolates showed an IS1296 profile different from all studied African and Australian ones. Similar results were obtained by Poumarat and Solsona (1995), who tested strains by restriction endonucleases BamHI and PstI. This investigation showed that outbreaks in Europe were not connected with the African endemic situation (Frey et al., 1995). Unconfirmed reports suggested that the disease may be present also in some other parts of Europe including Eastern Europe (Bashiruddin, 1996).

Hungary is considered free of this disease for more than 100 years. However, since Hungary has trade relations with many Western countries in cattle breeding materials and as respiratory diseases are frequent in herds, a decision was made to perform a complete examination in an attempt to detect $\mathrm{MmmSC}$ infection by pathological examination of lungs of cattle slaughtered at abattoirs, by testing their sera for specific antibodies to MmmSC by the complement fixation test (CFT) and by indirect ELISA, by culturing lung samples and nasal swabs for isolation of mycoplasmas as well as by testing them by PCR. 


\section{Materials and methods}

\section{Serological examination}

Serum samples were collected at three abattoirs from slaughtered cattle originating from all 20 counties of Hungary. Sera were also collected from 11 different farms situated in various counties of the country. Additionally, 60 sera were collected in four herds where 7 animals had suspicious CFT results $(++$ in dilution of 1:10).

All sera were tested in a dilution of 1:10 by the standard method of CFT of the Office International des Epizooties as indicated elsewhere (Campbell and Turner, 1994; Nicholas et al., 1996; Ayling et al., 1998) using standard antigen (obtained from IZSAM, Teramo, Italy). The control serum, also provided by the Teramo Institute, gave a titre of 1:320. Some of the sera (230) were tested with indirect ELISA and the latex slide agglutination test at the Veterinary Laboratories Agency, Addlestone, UK (R. Nicholas and R. Ayling).

\section{Examination of lungs and nasal swabs by culturing}

Lung samples were collected at abattoirs from slaughtered cattle at the same time when sera were collected. Additionally, nasal swabs were collected from the same 11 herds examined serologically. Part of the lung samples were cultured in liquid and solid medium B (Ernø and Stipkovits, 1973a, b) for presence of mycoplasmas by using a procedure described by Gourlay and Howard (1983). Part of the lung samples were cultured in Veterinary Mycoplasma Medium Liquid or CBPP diagnostic medium (both of them obtained from Dr. D. Windsor, Mycoplasma Experience, Reigate, Surrey, UK) supporting growth of MmmSC differentially and staining the colonies red. Isolates were identified on the basis of cultural and biochemical characteristics (Ernø and Stipkovits, $1973 b$ ), as well as serological properties using growth inhibition and epifluorescence tests. These media were used also for culturing a positive lung sample obtained as control from IZSAM, Teramo, Italy. MmmSC was isolated from this control in all three media.

\section{Examination of lungs and nasal swabs by PCR}

Testing of cattle lung samples and nasal swabs by PCR for the presence of $\mathrm{MmmSC}$ was performed by taking into consideration a possible presence of any other members of the M. mycoides cluster, as well as sequence differences in the 16S RNA operons and the different sensibility of methods and primers. Therefore the same primers and techniques used by FAIR1-CT95-711 project partners were applied: primers specific for the $M$. mycoides cluster and those that amplify only the DNA of M. mycoides subsp. mycoides small colony, large colony, and capri (Bashiruddin et al., 1994a, $b$; De Santis et al., 1996a, b). These primers were partly 
obtained from IZSAM, Teramo or custom synthesised. Additionally, primers for nested PCR specific for MmmSC were also used (Miserez et al., 1997).

Fifty nasal swab samples were collected in PBS from live animals in two large farms situated in two districts of the country. Nine hundred and fifty-three lung samples were collected from cattle slaughtered at three abattoirs. From 183 lungs, a $10 \%$ homogenised suspension was made in PBS. Five hundred $\mu$ laliquots of lung suspensions were applied for DNA isolation by phenol/chloroform extraction (De Santis et al., 1996a, b). In 133 cases, lung samples were cultured in Veterinary Mycoplasma medium (Mycoplasma Experience) and, after 24-48 h of incubation, $500 \mu \mathrm{l}$ of liquid medium was used for DNA extraction. Six hundred thirty-seven lung samples were precultured in Medium B (Ernø and Stipkovits, 1973a).

Five hundred $\mu \mathrm{l}$ aliquots of lung suspensions or cultures were centrifuged for $10 \mathrm{~min}$ at $14,000 \mathrm{~g}$. The sediments were washed once with $500 \mu \mathrm{TNE}$ puffer. The DNA was extracted according to the method described elsewhere (Bashiruddin et al., 1994a; De Santis et al., 1996a, $b$ ). The pellets were resuspended in $200 \mu \mathrm{l}$ of TNE puffer containing $20 \mu \mathrm{l}$ of $10 \%$ SDS, $20 \mu 1$ of $10 \%$ Sarcosyl and $5 \mu \mathrm{l}$ of Proteinase $\mathrm{K}(20 \mu \mathrm{g} / \mathrm{ml})$. After incubation for $1 \mathrm{~h}$ at $37^{\circ} \mathrm{C}$, DNA from the lysate was extracted once with $200 \mu \mathrm{l}$ of phenol saturated with $0.01 \mathrm{M}$ Tris-HCl, $\mathrm{pH} 7.2$ and $0.01 \mathrm{M}$ EDTA, and twice with $200 \mu \mathrm{l}$ of phenol: chloroform:isoamyl alcohol (25:24:1). The DNA was precipitated with $20 \mu \mathrm{l}$ of $3 \mathrm{M}$ sodium acetate and $300 \mu 1$ of cold ethanol and left overnight at $-20^{\circ} \mathrm{C}$. After centrifugation, the sediment was washed with $500 \mu \mathrm{l}$ of $70 \%$ ethanol, dried and resuspended in $10 \mu \mathrm{l}$ of deionised PCR grade water.

One $\mu l$ aliquots of extracted DNA samples were used for amplification in thermocycler PDR-91 ('Programmable DNA reproducer', BLS, Budapest, Hungary), using $50 \mathrm{pmol}$ of $M$. mycoides cluster specific primers (MC323/MC358; amplifying a $\sim 1500$ bp DNA fragment) (Taylor et al., 1992; Bashiruddin et al., $1994 b$ ), or the more specific primers detecting only M. mycoides subspecies mycoides SC, LC, and capri (MM450/MM451) (Taylor et al., 1992; Bashiruddin et al., 1994a, b; De Santis et al., 1996b), amplifying a $0.5 \mathrm{~kb}$ genome region. Primers described by Miserez et al. (1997) for the specific detection of MmmSC by nested PCR were used, too (717 and 503 bp amplicons, respectively). As control, DNA of M. mycoides subsp. mycoides SC (Afade strain), lung sample positive for MmmSC (IZSAM, Teramo) as well as DNA prepared from the MmmSC isolate cultured from the above-mentioned lung sample were used. The reaction mixture was $50 \mu \mathrm{l}$ consisting of $10 \mathrm{mM}$ Tris- $\mathrm{HCl}(\mathrm{pH} \mathrm{9.0),} 50 \mathrm{mM} \mathrm{KCl}, 1.5 \mathrm{mM}$ $\mathrm{MgCl}_{2}, 1.25 \mathrm{mM}$ of dNTPs, and $1.5 \mathrm{U}$ of Taq polymerase. PCR parameters were $94{ }^{\circ} \mathrm{C} 5 \mathrm{~min}$.; 30 cycles of $94{ }^{\circ} \mathrm{C}$ for $30 \mathrm{sec}, 50{ }^{\circ} \mathrm{C}$ for $30 \mathrm{sec}, 72{ }^{\circ} \mathrm{C}$ for $30 \mathrm{sec}$; finally $72{ }^{\circ} \mathrm{C}$ for $5 \mathrm{~min}$. The amplified products were analysed by gel electrophoresis, using $1 \%$ agarose containing ethidium bromide $(0.5 \mu \mathrm{g} / \mathrm{ml})$. The BIO-RAD 0.56-23.1 kb molecular weight standard or DNA of bacteriophage lambda digested by PstI were used as molecular mass marker. 
Sensitivity of all three sets of primers was tested using the control DNA prepared from a cultured isolate of $\mathrm{MmmSC}$ obtained from the positive lung samples $(167 \mathrm{ng} / \mu \mathrm{l})$. Two $\mu \mathrm{l}$ of the DNA dilutions $\left(10^{-1}-10^{-10}\right)$ was used as template in the PCR sensitivity test. Ten $\mu$ l of each $50 \mu$ final PCR product was analysed by electrophoresis.

\section{Results}

\section{Serological examination}

Altogether, 922 serum samples were collected at three abattoirs from slaughtered cattle originating from 62 large farms ( 3 to 25 animals, in an average of 14) and from 48 small farms (1-5 animals). Additional 266 sera were collected from 11 different farms situated in various counties of the country. All the 1188 sera were CFT negative except seven sera giving ++ in serum dilution of 1:10 (Table 1). Retesting of these sera gave negative results. Additionally, 30 sera were repeatedly collected in the four herds where the seven animals had these suspicious CFT results. These sera proved to be negative, too. Two serologically suspicious animals from two of the herds were slaughtered for observation of possible lesions. In one herd, none of the sacrificed animals had lesions, and no mycoplasma could be found by culturing or PCR. In case of the other animals, both had pneumonia and pleurisy. No MmmSC could be detected by culturing or PCR but other mycoplasmas like M. bovis were isolated from lungs and pleural fluid and M. bovirhinis from nasal swabs.

\section{Table 1}

Incidence of cattle reacting in the complement fixation test and of animals showing signs of pneumonia and pleurisy in the tested herds

\begin{tabular}{lccc}
\hline $\begin{array}{c}\text { Designation } \\
\text { of herd }\end{array}$ & $\begin{array}{c}\text { No. } \\
\text { of animals tested }\end{array}$ & $\begin{array}{c}\text { No. of serologically } \\
\text { reacting animals }\end{array}$ & $\begin{array}{c}\text { No. of animals } \\
\text { with pneumonia and pleurisy }\end{array}$ \\
\hline Zs & 16 & 1 & 11 \\
Sz1 & 16 & 1 & 11 \\
Sz2 & 17 & 1 & 6 \\
M & 17 & 4 & 4 \\
\hline
\end{tabular}

Sera from 100 cattle showing pneumonia and/or pleurisy and coming from 22 different farms, as well as sera from 130 animals of the same farms but having no pathological lesion were tested by indirect ELISA and latex slide agglutination in VLA, Addlestone (R. Nicholas and R. Ayling) and found negative. Twelve sera were tested also by immunoblot but CBPP characteristic profile was not found (J. Regalla, Laboratorios National de Investigacao Veterinaria, Lisboa, Portugal) 


\section{Culturing of lung and nasal swabs}

Nine hundred fifty-three lung samples were collected from slaughtered cattle at the same abattoirs where sera were collected. Additionally, 326 nasal swabs were collected from 11 herds (usually 30 animals/herd) situated in various counties of the country. All lung samples proved to be culturally negative for MmmSC. However, M. bovis (based on glucose and arginine negative properties, film and spot positive tests, growth inhibition and epifluorescence tests), and very rarely M. bovirhinis were present in certain samples.

\section{Pathological examination}

Altogether 685 (from 3 to 8 years old) animals, originating from 43 large farms (614 animals) and 26 small farms (71 animals) were examined for the presence of lung lesions (Table 2). Before sacrificing, the animals were clinically healthy. After slaughtering, 52 animals $(7.59 \%)$ were found by visual examination, palpation and incision to have macroscopic pneumonia alone or pneumonia and pleurisy (25.55\%) of different extent. Among animals of small farms, 17 cattle (23.94\%) had lesions while among cattle of large farms, 252 (34.69\%) had lesions. Animals without pathological lung lesions were found only in 7 large herds, in all other herds $6.67-100 \%$ of the animals had lung lesions.

Table 2

Occurrence of pneumonia and pleurisy in cattle examined at abattoirs

\begin{tabular}{|c|c|c|c|c|c|}
\hline $\begin{array}{c}\text { Type } \\
\text { of farms }\end{array}$ & $\begin{array}{c}\text { No. } \\
\text { of herds }\end{array}$ & $\begin{array}{c}\text { No. } \\
\text { of examined } \\
\text { cattle }\end{array}$ & $\begin{array}{l}\text { Occurrence } \\
\text { of pneumonia }\end{array}$ & $\begin{array}{l}\text { Occurrence } \\
\text { of pneumonia } \\
\text { with pleurisy }\end{array}$ & $\begin{array}{c}\text { No. } \\
\text { of cattle } \\
\text { with lesions }\end{array}$ \\
\hline Large farms & 43 & 614 & 51 & 162 & 213 \\
\hline$\%$ & & 100 & 8.31 & 26.38 & 34.69 \\
\hline Small farms & 26 & 71 & 1 & 16 & 17 \\
\hline$\%$ & & 100 & 1.41 & 22.54 & 23.95 \\
\hline Total & 69 & 685 & 52 & 178 & 230 \\
\hline$\%$ & & 100 & 7.59 & 25.79 & 33.38 \\
\hline
\end{tabular}

Lesions were characterised by sero-fibrinous pneumonia localised mostly in apical and cardiac lobes unilaterally. In case of pneumonia and pleurisy, lesions were found in diaphragmatic lobes, adhesions connected the thickened visceral pleural and parietal pleura, and also pleural fluid was present. In case of fibrinous lesions and pleurisy, the septa of lobes were slightly thickened. By palpation and incision, small areas of necrotic parenchyma surrounded by fibrous capsule was noticed. The affected area had both old and recent damage. No sequesters or hepatisation was found. 


\section{PCR examination of lung and nasal swabs}

Fifty nasal swabs and 430 lung samples were examined by M. mycoides cluster primers, 325 lung samples were tested by a more specific primer pair, and 198 samples by nested PCR. All the DNA extracts from lung suspension, nasal swabs or cultures were found to be negative in PCR regardless of the method or primers used (Fig. 1). The sensitivity of the methods was tested, and the detection level was found to be $33.4 \mathrm{pg}$ DNA for the $M$. mycoides cluster specific primers and the more specific primers, and $0.33 \mathrm{pg}$ in nested PCR (Fig. 2A, B and C).

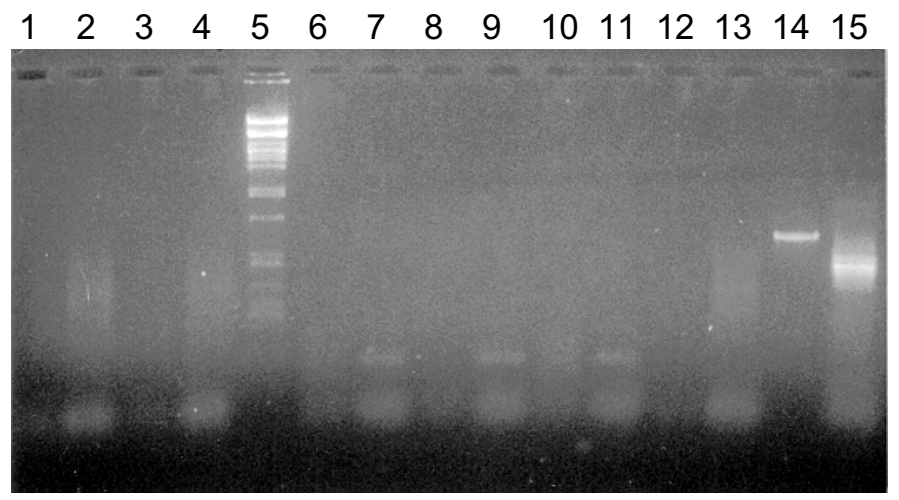

Fig. 1. Agarose gel electrophoresis of PCR products resulted from amplification of DNA extracted from bovine lung samples. Applied primers: Mycoplasma mycoides subspecies mycoides SC species specific primers designed for nested PCR assay (a., SCNEST-1L and SCNEST-1R in the first PCR reaction, b., SC3VII and SC3IV in the second PCR reaction). A 10- $\mu 1$ quantity of each $50 \mu 1$ final PCR product was analysed by electrophoresis. Lanes 1 and $2=$ negative lung tissues from first (a) and second (b) PCR reaction. Lanes 3, 6, 8, 10 and $12=$ field lung samples from first reaction, lanes $4,7,9,11$ and $13=$ the same field lung samples from second reaction. Lane $5=\lambda$ DNA

(PstI digested). Lanes 14 and 15 $=$ MmmSC from first and second reaction

\section{Discussion}

According to the presented data, macroscopic pneumonia and pleurisy are frequently seen in animals originating from Hungarian cattle herds and slaughtered at abattoirs. In certain herds, the incidence of these lesions is very high, reaching $100 \%$. The lesions are not fully identical with those caused by $M$. $m y$ coides subsp. mycoides SC (Nicholas et al., 1996) but in chronic cases they are similar. Since MmmSC can cause also very mild lesions (Bashiruddin et al., 1996), pathomorphologic examination of cattle for MmmSC infection is not sufficient. This problem should be stressed, taking into consideration also the frequent use of antibiotics which might suppress the development of lesions. 


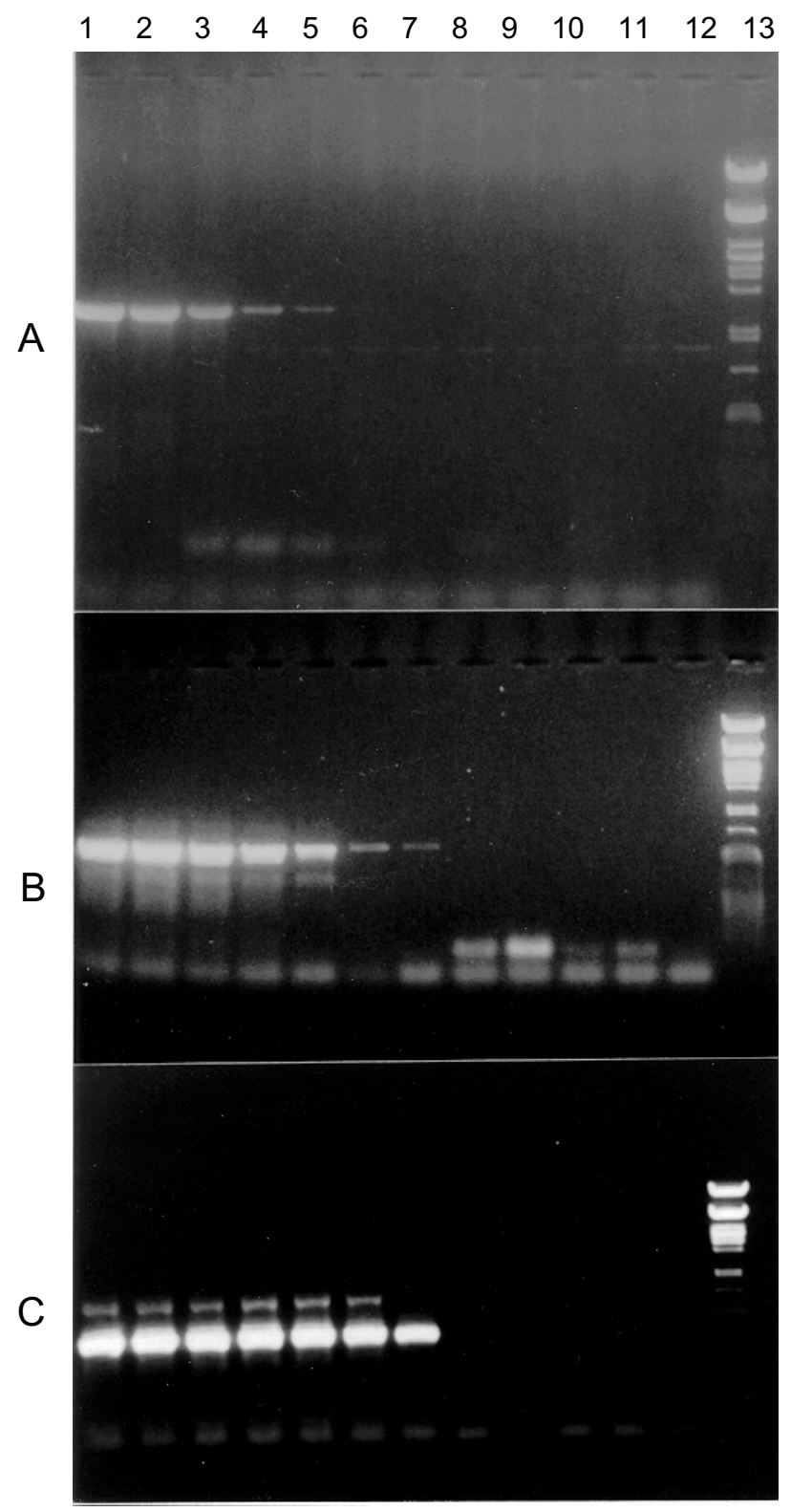

Fig. 2. Template DNA titration. The original concentration of the DNA used as positive control in our PCR assays was $167 \mathrm{ng} / \mu \mathrm{l}$. Two $\mu 1$ of the DNA dilutions $\left(10^{-1}-10^{-10}\right)$ were used as template in the PCR sensitivity test. Agarose gel electrophoresis of PCR products of DNA extracted from M. mycoides subsp. mycoides SC and amplified with: A. Mycoplasma mycoides cluster specific primers (MC358, MC323), B and C. MmmSC specific primers designed for nested PCR assay (SCNEST-1L and SCNEST-1R, SC3VII and SC3IV, respectively).

Lane $1=$ undiluted DNA, lanes $2-11=$ tenfold diluted DNA $\left(10^{-1}-10^{-10}\right)$, lane $12=$ negative control, lane $13=\lambda$ DNA $($ Pst $\mathrm{I}$ digested $)$ 
The CFT gave negative results in most of the cases. However, frequent antibiotic treatment of animals may also prevent the development of antibodies. Since the age of animals slaughtered at abattoirs was high (mostly more than three to eight years), absence of antibodies could be explained also by age. Finally, not all infected animals develop antibodies (Le Goff and Lefevre, 1989; Poumarat et al., 1989; Nicholas et al., 1996).

In the present study sera from seven cattle gave weak $(++)$ reactions in the CFT. However, these animals proved to be negative by culturing and PCR. Retesting of the sera by CFT or ELISA and examination of additional serum samples and nasal swabs collected from questionable herds serologically, by culturing or by PCR, respectively, always gave negative results. These data confirm the absence of MmmSC infection in Hungary. The cause of the false positive reactions is unknown. However, it should be stressed that the occurrence of such reactions makes it necessary to perform a complex re-examination of such herds by methods including the very sensitive PCR.

Negative results of PCR for MmmSC as well as for M. mycoides cluster convincingly indicate the absence of infection. However, in our studies, examination was performed on a limited number of animals. Therefore the systematic testing of animals should be continued mostly in farms where respiratory disease is a major problem.

Since $M$. bovis could be isolated from lungs, its causative role in the development of lung lesions might be supposed (Ter Laak, 1992b). Lesions induced by M. bovis might be similar to CBPP lesions. This causes problems in diagnosis based exclusively on macroscopic examination of the lungs, and again stresses the necessity of performing regular complex (clinical, pathomorphological, serological, microbiological and PCR) studies to exclude the presence of CBPP in Hungary.

\section{Acknowledgements}

The authors acknowledge R. Nicholas and R. Ayling for performing latex agglutination and indirect ELISA tests and J. Regalla for completing immunoblotting. This work was performed in the framework of the FAIR1-CT95-0711 program aided by grants EU-000042/98 of the National Committee for Technological Development, and A312 of the Hungarian Scientific Research Fund (OTKA), Budapest, Hungary.

\section{References}

Akane, A., Matsubara, K., Nakamura, H., Takahashi, S. and Kimura, K. (1994): Identification of the heme compound copurified with deoxyribonucleic acid (DNA) from bloodstains, a major inhibitor of polymerase chain reaction (PCR) amplification. J. Forensic Sci. 39, 362-372. 
Ayling, R., Regalla, J., Spencer, Y., Nicholas, R. and De Santis, P. (1998): Investigation on a CBPP outbreak in Portugal. COST 826. Agriculture and Biotechnology. Mycoplasmas of Ruminants: Pathogenicity, Diagnostics, Epidemiology and Molecular Genetics, pp. 117-120.

Bashiruddin, J. B. (1996): Observation from outbreaks of CBPP in Europe and Africa. COST 826. Agriculture and Biotechnology. Mycoplasmas of Ruminants: Pathogenicity, Diagnostics, Epidemiology and Molecular Genetics, pp. 150-154.

Bashiruddin, J. B., Nicholas, R. A. J., Santini, F. G., Ready, R. A., Woodward, J. and Taylor, T. K. (1994a): Use of the polymerase chain reaction to detect mycoplasma DNA in cattle with contagious bovine pleuropneumonia. Vet. Rec. 134, 240-241.

Bashiruddin, J. B., Taylor, T., K. and Gould, A. R. (1994b): A PCR-based test for the specific identification of Mycoplasma mycoides subspecies mycoides SC. J. Vet. Diagn. Invest. 6, 428-434.

Campbell, A. D. and Turner, A. W. (1994): Studies on contagious pleuropneumonia of cattle. VI. An improved complement fixation test. Aust. Vet. J. 29, 154-163.

Cheng, X. X., Nicolet, J., Poumarat, F., Regalla, J., Thiacourt, F. and Frey, J. (1995): Insertion element IS1296 in Mycoplasma mycoides subsp. mycoides small colony identifies an European clonal line distinct from African and Australian strains. Microbiol. 141, 3221-3228.

Dedieu, L., Mady, V. and Lefevre, P. C. (1994): Development of a selective polymerase chain reaction assay for the detection of Mycoplasma mycoides subsp. mycoides SC (contagious bovine pleuropneumonia agent). Vet. Microbiol. 42, 327-339.

De Santis, P., Bashiruddin, J. B., Ayling, R., Nicholas, R. A. J. and Regalla, J. (1996a): Sample treatment and detection of Mycoplasma mycoides subsp. mycoides SC DNA from a CBPP outbreak in Northern Portugal. COST 826. Agriculture and Biotechnology. Mycoplasmas of Ruminants: Pathogenicity, Diagnostics, Epidemiology and Molecular Genetics, pp. 121-124.

De Santis, P., Visaggio, M. and Bashiruddin, J. B. (1996b): Application of Mycoplasma mycoides subsp. mycoides PCR to Italian field samples. COST 826. Agriculture and Biotechnology. Mycoplasmas of Ruminants: Pathogenicity, Diagnostics, Epidemiology and Molecular Genetics, pp. 141-143.

Egwu, G. O., Nicholas, R. A. J., Ameh, J. A. and Bashiruddin, J. B. (1996): Contagious bovine pleuropneumonia: an update. Vet. Bull. 66, 875-888.

Ernø, H. and Stipkovits, L. (1973a): Bovine mycoplasmas: Cultural and biochemical studies. I. Acta Vet. Scand. 14, 436-449.

Ernø, H. and Stipkovits, L. (1973b): Bovine mycoplasmas: Cultural and biochemical studies. II. Acta Vet. Scand. 14, 500-516.

Frey, J., Cheng, X., Poumarat, F., Thiaucourt, F., Regalla, J. and Nicolet, J. (1995): Molecular epidemiology of Mycoplasma mycoides subspecies mycoides SC using insertion element IS 1296. COST 826. Agriculture and Biotechnology. Mycoplasmas of Ruminants: Pathogenicity, Diagnostics, Epidemiology and Molecular Genetics, pp. 21-23.

Gourlay, R. N. and Howard, C. J. (1983): Recovery and identification of bovine mycoplasmas. In: Tully, J. G. and Rasin, S. (eds) Methods in Mycoplasmology. Vol. 2. Academic Press, New York, pp. 81-89.

Hotzel, H. and Sachse, K. (1996): Differentiation of the Mycoplasma mycoides cluster using PCR scheme. COST 826. COST 826. Agriculture and Biotechnology. Mycoplasmas of Ruminants: Pathogenicity, Diagnostics, Epidemiology and Molecular Genetics, pp. 19-20.

Johansson, K. E., Bölske, G. and Pettersson, B. (1996): The phylogeny of the Mycoplasma mycoides cluster based on 16S rRNA sequence analysis. COST 826. Agriculture and Biotechnology. Mycoplasmas of Ruminants: Pathogenicity, Diagnostics, Epidemiology and Molecular Genetics, pp. 16-18.

Le Goff, C. and Lefevre, P. C. (1989): Contagious bovine pleuropneumonia: immunoenzymatic test and kinetics of antibody formation in experimental infection. Relation of complement fixation, excretion and the study of circulating antigen. Rev d'Elevage et de Med. Vet. des Pays Tropicaux 42, 365-369. 
Miserez, R., Pilloud, T., Cheng, X., Nicolet, J., Griot, C. and Frey, J. (1997): Development of a sensitive nested PCR method for the specific detection of Mycoplasma mycoides subspecies mycoides SC. Mol. Cell. Probes 11, 103-111.

Nicholas, R. A. J. and Bashiruddin, J. B. (1995): Mycoplasma mycoides subspecies mycoides (small colony variant): the agent of contagious bovine pleuropneumonia and member of the 'Mycoplasma mycoides cluster'. J. Comp. Path. 113, 1-27.

Nicholas, R. A. J. and Palmer, N. (1994): Contagious bovine pleuropneumonia in Europe. State Vet. J. 4, 14-16.

Nicholas, R. A. J., Santini, F. G., Clark, K. M., Palmer, M. A., De Santis, P. and Bashiruddin, J. B. (1996): A comparison of serological tests and gross lung pathology for detecting contagious bovine pleuropneumonia in two groups of Italian cattle. Vet. Rec. 139, 89-93.

Petterson, B., Leitner, T., Ronaghi, M., Bölske, G., Uhlen, M. and Johansson, E. (1996): Phylogeny of the Mycoplasma mycoides cluster as determined by sequence analysis of the $16 \mathrm{~S}$ rRNA genes from the two rRNA operons. J. Bacteriol. 178, 4131-4142.

Poumarat, F. and Solsona, M. (1995): Molecular epidemiology of Mycoplasma mycoides subsp. mycoides biotype small colony, the agent of contagious bovine pleuropneumonia. Vet. Microbiol. 47, 305-315.

Poumarat, F., Perrin, M., Belli, O. P. and Martel, J. L. (1989): Correlation of the excretion of mycoplasma and kinetics of antibodies detected by complement fixation, passive hemagglutination and rapid seroagglutination in Mycoplasma mycoides subsp. mycoides SC experimental infection in cattle. Rev d'Elevage et de Med. Vet. des Pays Tropicaux 42, 357-364.

Rweyemamu, M. M. and Benkirane, S. (1996): Global impact of infections with organisms of the 'Mycoplasma mycoides cluster' in ruminants. COST 826. Agriculture and Biotechnology. Mycoplasmas of Ruminants: Pathogenicity, Diagnostics, Epidemiology and Molecular Genetics, pp. 1-11.

Santini, F. G., D'Angelo, A. R., Scacchia, M., Di Giannatale, E., Visaggio, M. C., Farinelli, G., Di Francesco, G. and Guarducci, M. (1992): Sequestro polmonare in un bufalo domestico de Mycoplasma mycoides subsp. mycoides SC: isolamento, quadro anatomo-istopatologico ed immunoistochimico. Vet. Ital. 4, 4-10.

Taylor, T. K., Bashiruddin, J. B. and Gould, A. R. (1992): Relationship between members of the Mycoplasma mycoides cluster as shown by DNA probe and sequence analysis. Int. J. Syst. Bact. 42, 594-597.

Ter Laak, E. A. (1992a): Contagious bovine pleuropneumonia. A review. Vet. Quart. 14, 104-110.

Ter Laak, E. A. (1992b): Mycoplasma of the bovine respiratory tract. Thesis. Utrecht Univ., The Netherlands. 